\title{
Comparison of aquatic macrophyte community structure between natural wetlands and rice fields with different cultivation ages
}

\author{
A. S. Rolon ${ }^{a *}$, R. S. Godoy ${ }^{b}$ and L. Maltchik

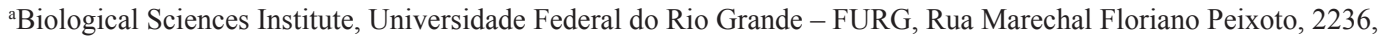 \\ CEP 96170-000, São Lourenço do Sul, RS, Brazil \\ ${ }^{\mathrm{b}}$ Ecology and Conservation of Aquatic Ecosystems, Universidade do Vale do Rio dos Sinos - UNISINOS, \\ Av. Unisinos, 950, CEP 93022-750, São Leopoldo, RS, Brazil \\ *e-mail: asrolon@furg.br
}

Received: March 29, 2016 - Accepted: October 06, 2016 - Distributed: May 31, 2018

(With 5 figures)

\begin{abstract}
Recent studies indicate that rice fields contribute to the conservation of aquatic plants, however, repeated cultivation can reduce the species diversity harbored by rice fields. Repeated tillage, agrochemical application and environmental homogeneity can reduce plant diversity and select for species more tolerant to disturbance. Our hypotheses were: 1) macrophyte richness and biomass decrease with increased rice crop age; and 2) macrophyte species of rice fields are a subsample of natural wetlands and species loss will increase with crop age. We investigated three rice fields of each different ages (old, intermediate and new ones) and three natural intermittent wetlands for this study. Each area was sampled four times throughout the rice cultivation cycle (off-season, initial growth, final growth and post-harvest). Our results showed that the mean macrophyte richness and biomass were similar between rice fields of different ages and lower than that of natural wetlands. Although species composition in the different-aged rice fields was not markedly different, there was nestedness in the rice fields as age increased. In this study, we verified that macrophyte richness and biomass in rice fields was lower than natural wetlands and the species composition was different among wetland types (rice fields and natural wetlands), however our hypothesis that species richness and biomass will decrease with crop age was not confirmed. All rice crops had similar macrophyte assemblage structure (richness, biomass and species composition). However, the another hypothesis tested was confirmed, macrophyte assemblage of rice fields is a subset of natural wetlands and as, the age of a rice field increases, the species that occur in older rice field are subsets of species that occur in younger ones.
\end{abstract}

Keywords: agriculture, conservation of biodiversity, southern Brazil, species loss.

\section{Comparação da estrutura da comunidade de macrófitas aquáticas entre áreas úmidas naturais e arrozais com diferentes tempos de cultivo}

\begin{abstract}
Resumo
Estudos recentes indicam que arrozais contribuem para a conservação de plantas aquáticas, entretanto cultivos repetidos podem reduzir a diversidade de espécies nos arrozais. Cultivos repetidos, aplicação de agrotóxicos e homogeneização ambiental podem reduzir a diversidade de plantas e selecionar espécies mais tolerantes a perturbações. Nossas hipóteses foram: 1) a riqueza e a biomassa de macrófitas reduzem com o aumento do tempo de cultivo dos arrozais; e 2) as espécies de macrófitas aquáticas dos arrozais são subamostras das áreas úmidas naturais e a perda de espécies aumentará com o tempo de cultivo. Nós investigamos três arrozais de cada uma das diferentes idades (antigos, intermediários e novos) e três áreas úmidas naturais temporárias. Cada área foi amostrada quatro vezes ao longo do ciclo de cultivo (resteva, crescimento inicial, crescimento final e pós-colheita). Nossos resultados indicaram que a riqueza e a biomassa média de macrófitas foram similares entre os arrozais de diferentes idades e menor do que nas áreas úmidas naturais. Embora a composição de espécies nos arrozais de diferentes idades não tenha sido marcadamente diferente, houve aninhamento nos arrozais e este aumentou com tempo de cultivo do arrozal. Neste estudo, nós verificamos que a riqueza e biomassa de macrófitas nos arrozais eram menores que nas áreas úmidas naturais e a composição de espécies era diferente entre os tipos de áreas úmidas (arrozais e áreas úmidas naturais), entretanto nossa hipótese de que a riqueza e a biomassa de macrófitas diminuiriam com a idade do cultivo não foi confirmada. Todos os arrozais foram similares quanto à estrutura da assembleia de macrófitas (riqueza, biomassa e composição de espécies). No entanto, a outra hipótese testada foi confirmada, a assembleia de macrófitas dos arrozais é um subconjunto das áreas úmidas naturais e, conforme aumenta a idade do arrozal, as espécies que ocorrem nos arrozais mais antigos são subconjuntos das espécies que ocorrem nos mais jovens.
\end{abstract}

Palavras-chave: agricultura, conservação da biodiversidade, sul do Brasil, perda de espécies. 


\section{Introduction}

Most of the world's biodiversity lies in areas managed by humans (Pimentel et al., 1992), and biodiversity has also been conserved outside of protected areas (Chester and Robson, 2013). Conversion of natural ecosystems to agricultural lands results in high species loss (Vallan, 2002). Studies that investigate implications of different management techniques on biodiversity conservation have gained importance. Some studies demonstrated that rice fields contribute to maintain a rich biodiversity, especially in areas where natural wetlands have been completely replaced by rice production, such as California's Central Valley (Reid and Heitmeyer, 1995). Rice fields are important habitats for macrophyte development and these agroecosystems could harbor rare and important species (Bambaradeniya et al., 2004; Linke et al., 2014; Rolon and Maltchik, 2010). Rice fields have specific characteristics, such as periodic flooding, that make them similar to temporary wetlands. These agroecosystems can help maintain regional biodiversity by acting as supplemental habitats for many species of macrophytes, invertebrates, amphibians, birds and fishes throughout the world (Bambaradeniya and Amerasinghe, 2004; Lawler, 2001; Maltchik et al., 2011; Marambe et al., 2009; Rolon and Maltchik, 2010). Although rice may help conserve wetland diversity, the effects of rice production on biodiversity could vary with production techniques (Linke et al., 2014).

Rice is irrigated with water diverted from natural freshwater systems. Irrigated rice fields use about $40 \%$ of the world's irrigation water, and $75 \%$ of the world's rice is produced on about 80 million hectares of lowland irrigated rice fields (IRRI, 2013). Over the past 50 years, the rice area planted has increased $40 \%$ throughout the world (FAO, 2013), and this area has increased $26 \%$ in southern Brazil. Increased demand for rice and the abandonment or resting of areas due to soil infertility, pests and diseases and water deficit have led to the conversion of new areas into rice fields. In the main rice-producing region in Brazil (southern Brazil), $4 \%$ of the country is cultivated annually (11 million ha).

The representative contribution of rice fields in the economy of southern Brazil and the rising rice production have led to a landscape mosaic of natural wetlands and rice fields that have been cultivated for different lengths of time. The role of these agroecosystems in macrophyte conservation and the impact of management used in these areas on the successional dynamics of the macrophyte communities are of high interest. Macrophyte diversity in southern Brazil can reach up to 500 species and wetland loss by rice field conversion can compromise several macrophyte species, including endemic ones (Maltchik and Rolon, 2004). Recent studies indicate that rice fields contribute to the conservation of some macrophytes in southern Brazil (Linke et al., 2014; Rolon and Maltchik, 2010), however aquatic macrophyte diversity and composition in rice fields differs significantly from natural wetlands and the cultivation cycles reduces macrophyte richness
(Linke et al., 2014). The intensification of rice cultivation, use of fertilizer and pesticides, and mismanagement of soil may decrease the importance of rice fields as biological refuges. We suppose that repeated cultivation can reduce the species diversity harbored by rice fields, because repeated tillage, agrochemical application and environmental homogeneity can select for species more tolerant to disturbance, then reduce plant diversity and alter assemblage composition. Species capable of adapting to the agricultural landscape may be limited directly by the disturbance regimes and rice management techniques, which can lead to shifts in species composition (McLaughlin and Mineau, 1995). In this sense, our hypotheses were: 1) macrophyte richness and biomass decrease with increased rice crop age; and 2) macrophyte species of rice fields are a subsample of natural wetlands and species loss will increase with crop age.

\section{Material and Methods}

\subsection{Study area}

The coastal plain of southernmost state in Brazil (Rio Grande do Sul) is an important rice production area in South America. This region concentrates a high density and diversity of wetlands in southern Brazil, with high macrophyte diversity. The climate is subtropical humid and the average annual temperature is $17.5^{\circ} \mathrm{C}$, ranging between $4.6{ }^{\circ} \mathrm{C}$ in winter and $22.2^{\circ} \mathrm{C}$ in summer. Average rainfall reaches $1250 \mathrm{~mm} \cdot \mathrm{yr}^{-1}$ and ranges from 1150 to $1450 \mathrm{~mm} \cdot \mathrm{yr}^{-1}$. Although there are occasional drought periods during the summer, historical data indicates regular rainfall distribution throughout the year. The study took place in Sentinela do Sul, one of coastal plain cities known for its historical rice production (Figure 1). In this region there are rice fields of different ages and natural wetlands under similar landscape pattern.

\subsection{Data collection}

The rice fields ( 1 ha) were classified according to cultivation age in the following categories: 1) old crops - fields cultivated for the past 15 to 20 years; 2) intermediate crops - fields cultivated for five to 10 years; and 3) new crops - fields cultivated for a maximum of three years. All rice fields of studied farmland (51 $37^{\prime}-51^{\circ} 42^{\prime} \mathrm{W} ; 30^{\circ} 42^{\prime}-30^{\circ} 46^{\prime} \mathrm{S}$ ) were mapped by satellite images. We also identified all natural temporary wetlands close to the rice fields $(2 \mathrm{~km})$. The natural temporary wetlands had similar characteristics of rice fields: 1) hydroperiod between 8 and 10 months; 2) maximum water depth of $40 \mathrm{~cm}$; and 3) area between 0.8 and 1.2 ha. Then we randomly sampled three crops of each age class (old, intermediate and new) and three natural temporary wetlands, herein natural wetlands, for the study (Figure 1).

We sampled each area four different times throughout the rice cultivation cycle (August/2011 to June/2012), coinciding with the main stages of rice cultivation: off-season (August/2011), initial growth (January/2012), final growth (March/2012) and post-harvest (June/2012). Off-season is the period in which the areas do not produce rice, and 


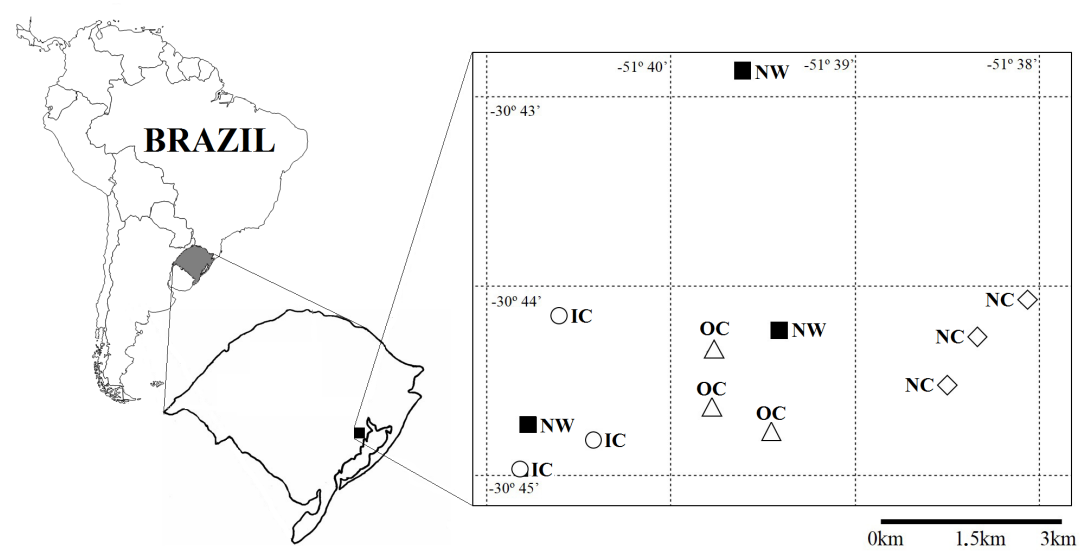

Figure 1. Rice fields and natural wetlands in southern Brazil. A total of three new crops (NC), three intermediate crops (IC), three old crops $(\mathrm{OC})$ and three natural intermittent wetlands $(\mathrm{NW})$ were sampled over the rice cultivation cycle.

the presence of water during this period is associated with precipitation and slope, where water pooled intermittently in the lower portions of the land. During the cultivation phases, the presence of standing water is associated with rice growth, and water depth during the initial growth period was $20 \mathrm{~cm}$, reaching up to $40 \mathrm{~cm}$ during the final growth period. The fields were drained during the post-harvest period. Natural wetlands dried up or had a significantly decreased floodplain area from December to March, which coincided with summer and flooding of the rice fields. Water depth varied from 20 to $50 \mathrm{~cm}$ in the autumn and winter and dried up in the summer (two to four months). The natural hydrology of the wetlands did not follow that of the rice crops from October to May. However, the hydroperiod of crops and natural wetlands was similar, c.a. 8 months.

Macrophyte richness and biomass was sampled by the quadrat method. Eight quadrats were randomly sampled $(30 \mathrm{~cm} \times 30 \mathrm{~cm})$ within each rice crop or natural wetland. The quadrats were randomly placed along four transects over each plot (crop or natural wetland). Terrestrial species and rice seedlings were excluded from the samples. All of the aboveground biomass was collected from each quadrat (roots and other subterranean fragments were not considered) and washed to remove periphyton and organic/ inorganic material. The plants were separated by species and dehydrated in an oven at $60^{\circ} \mathrm{C}$ until they reached a constant mass (about $72 \mathrm{~h}$ ). Macrophyte biomass was expressed in grams of dry mass per square meter (gDM.m $\left.\mathrm{m}^{-2}\right)$, and richness corresponded to the number of species in each quadrat. Due to the impossibility of taxonomic differentiation between species of the genus Eleocharis R. Br. during periods without flowers, these species were grouped at the genus level. We used a broad definition of aquatic macrophyte, which includes submerged, floating-leaf and emergent plants (herbs, shrubs and trees) and covers a wide taxonomic range (Charophytes, Bryophytes, Pteridophytes, and Spermatophytes).

\subsection{Data analysis}

For all analyses, the quadrats were considered subsamples, then the data of eight quadrats of each plot level were collapsed into a single sample unit (replica) for each of the four wetland types (natural wetland, old crops, intermediate crops and new crops) at each time level (sampling periods, $\mathrm{n}=4$ ). The sampling unit was therefore plot per time ( 12 plots $\times 4$ times). Richness corresponded to the number of accumulated species at each wetland type at each time. Biomass corresponded to the sum of the dry mass of all of the species collected at each wetland type at each time.

We tested variation in macrophyte richness and biomass among old crops, intermediated crops, new crops and natural wetlands over the cultivation cycle with a Mixed Design ANOVA, which is a combination of a repeated measures variable (time) and a between-groups variable (wetland type). The ANOVA design was two-way (wetland type $\mathrm{x}$ time) with 48 observations ( 3 plots $\mathrm{x} 4$ wetland type $\mathrm{x} 4$ times). The two factors were treated as fixed and an interaction between factors was included. The temporal variation hypothesis was tested using polynomial contrasts and the wetland system difference hypotheses were tested using Helmert contrasts; 1: natural wetlands vs (new, intermediate and old crops); 2 : new crops vs (intermediate and old crops) and; 3: intermediate crops vs old crops. The homogeneity of variances was tested using Mauchly's test statistic, where sphericity of the F-ratio is assumed if differences are not significant $(\mathrm{p}>0.05)$. The main effects were compared using Bonferroni adjustment. To guarantee homoscedacity of the data, biomass values were transformed to $\log 10$ (biomass +1 ). The analyses were performed using PASW Statistics 18 (Predictive Analytics SoftWare), release version 18.0.0. (IBM, 2009). 
We use a Principal Coordinates Analysis (PCoA) to explore the differences of the species composition in different wetlands types and time. The ordination was carried out with a Bray-Curtis distance and using sums of biomass of each macrophyte species of natural wetlands $(n=3)$, new crops $(n=3)$, intermediate crops $(n=3)$ and old crops $(n=3)$ at each time, resulting in 16 observations (4 times $x 4$ wetland types). The objective was to highlight differences in the temporal dynamics of the macrophyte community in the four studied wetland types. We tested for differences in species composition among natural wetlands, old crops, intermediate crops and new crops with a Multivariate Permutational Variance Analysis (PERMANOVA) with Bray-Curtis distance and validation by 5000 permutations (design $3 \times 4 \times 4$ ). We used an Indicator Species Analysis (De Cáceres et al., 2010) by correlation index (r) to determine which species were specific to natural wetlands, old crops, intermediate crops and new crops. The significance of the discriminatory power of species was tested with 1000 permutations.

The occurrence of nestedness was evaluated with a nestedness metric based on overlap and decreasing fill - NODF (Almeida-Neto et al., 2008). NODF assumes values between 0 (no nestedness) and 100 (communities perfectly nested) and enables the evaluation of nestedness between locations and between species separately. Since we hypothesized that nestedness existed between locations, only the NODF values for locations (NODFrows) were considered. Furthermore, we ordinated the presence-absence matrix according to the gradual species loss with length of agricultural cultivation time (natural wetlands, new crops, intermediate crops and old crops). To test nestedness significance, a "quasiswap" algorithm was used as the null model (using column marginal frequencies as probabilities) and 1000 simulations to validate significance of the model.

The species co-occurrence pattern (positive, negative and random association) was tested by probabilistic model of pair-wise species co-occurrence (Veech, 2013). The probabilistic model or species co-occurrence was based on observed and expected frequencies of pair-wise species co-occurrence; and the expected frequency is based on each species distribution being random and independent of other species (Griffith et al., 2014). The analyses were carried out with natural wetlands $(n=3)$, new $(n=3)$, intermediate $(n=3)$ and old crops $(n=3)$ separately, according the presence and absence of species in each wetland type over cultivation cycle (4 times). The association was considered significant at $\mathrm{P}<0.05$ greater than expected (positive association) and lower than expected (negative associations). The analyses were performed using R software, release version 2.15.1. (R Core Team, 2012).

\section{Results}

We collected a total of 45 macrophyte species in the three natural wetlands and 35 species in the nine rice fields (Table 1). A total of 19 species were exclusive to natural wetlands and 26 species were shared by the natural wetlands and rice fields. Natural wetlands shared 17 species with new and intermediate crops and 13 species with old crops. The three rice field types shared only nine species.

Poaceae, Cyperaceae and Plantaginaceae species represented approximately $33 \%$ of all the species. In natural wetlands, most of the macrophyte species were hydrophytes, which depend heavily on standing water - submersed and floating (56\%) and emergent and amphibious accounted for $44 \%$ of the total species. In rice fields, emergent and hydrophyte species had similar values, 51\% and 49\% respectively. Most species were native, except Centella asiatica (L.) Urb. (registered in all wetland systems). Among of 45 species of natural wetlands, 73\% were perennial, $7 \%$ were annual and $20 \%$ can be either annual or perennial according to hydroperiod. In rice crops, $80 \%$ were perennial, $6 \%$ were annual and $14 \%$ can be either annual or perennial.

The species Bacopa monnieri (L.) Wettst., Centella asiatica, Cyperus berroi (C.B. Clarke) Barros, Eleocharis spp., Heteranthera reniformis Ruiz \& Pav., Ludwigia peploides (Kuntze) P.H. Raven, Luziola peruviana Juss. ex J.F. Gmel., Nymphoides indica (L.) Kuntze, Paspalum distichum L., Pontederia cordata L., Scirpus submersus C. Wright and Utricularia gibba L. occurred in all natural wetlands. The most frequent species in rice fields were Leersia hexandra Sw. (89\% or rice fields), Eleocharis spp. (78\%), Sagittaria montevidensis Cham. \& Schltdl. (67\%), Heteranthera reniformis (56\%), Ludwigia peploides (56\%), Pontederia cordata (56\%) and Chara sp. (56\%).

Species richness varied throughout time $\left(\mathrm{F}_{3,24}=7.204\right.$; $p=0.001$; Mauchly's test, $p=0.568)$ and there was no interaction between wetland types and time $\left(\mathrm{F}_{9,24}=1.093\right.$; $p=0.404)$. Species richness in initial growth was lower than final growth $(p=0.001)$. Richness varied among

Table 1. Total macrophyte richness of natural wetlands $(n=3)$, new crops $(n=3)$, intermediate crops $(n=3)$ and old crops $(n=3)$ over rice cultivation cycle of southern Brazil.

\begin{tabular}{lccccc}
\hline & $\begin{array}{c}\text { Natural } \\
\text { wetlands }\end{array}$ & New crops & $\begin{array}{c}\text { Intermediate } \\
\text { crops }\end{array}$ & Old crops & Total \\
\hline Off-season (OS) & 21 & 13 & 9 & 4 & 30 \\
Initial growth (IG) & 17 & 1 & 0 & 7 & 20 \\
Final growth (FG) & 34 & 14 & 9 & 6 & 41 \\
Post-harvest (PH) & 30 & 11 & 16 & 8 & 36 \\
Total & 45 & 24 & 23 & 16 & 54 \\
\hline
\end{tabular}


wetland types $\left(\mathrm{F}_{3,8}=24.292 ; p<0.001\right.$; Figure 2). Natural wetlands had more species than crops (temporary wetlands vs [new, intermediate, old]; difference $=9.806 ; p<0.001$ ), but species richness was similar between new and other crops (new vs [intermediate, old]; difference $=0.458$; $p=0.719$ ) and intermediate and old crops (intermediate vs old; difference $=1.417 ; p=0.347$ ).

Species biomass did not vary throughout time $\left(\mathrm{F}_{3,24}=1.822 ; p=0.170\right.$; Mauchly's test, $\left.p=0.404\right)$ and there was no interaction between wetland types and time $\left(\mathrm{F}_{9,24}=0.934 ; p=0.514\right)$. However, biomass varied among wetland types $\left(\mathrm{F}_{3,8}=189.346 ; p<0.001\right.$; Figure 3$)$. Natural wetlands had more biomass than crops (temporary wetlands vs [new, intermediate, old]; difference $=1.432 ; p<0.001$ ), but species biomass was similar between new and other crops (new vs [intermediary, old]; difference $=-0.024$; $p=0.718$ ) and intermediate and old crops (intermediate vs old; difference $=0.071 ; p=0.362$ ).

The first two axes of the PCoA explained $50.7 \%$ of the variation in species composition; the first axis explained $31.2 \%$ and the second axis explained $19.5 \%$ (Figure 4 ). The difference in species composition between crops of different ages was not clear; however, the macrophyte composition of different-aged crops was more similar during the off-season period than cultivation and post-harvest periods (Figure 4). The amplitude of variation of species composition in natural wetlands was less than the observed for the three crop types (Figure 4). This result indicated that the temporal species substitution was higher in the crops than in natural wetlands. Besides, the similarity between off-season (beginning of cultivation cycle) and post-harvest (end of cultivation cycle) was higher in new crops than others.
Macrophyte composition varied among the wetland types studied $\left(\mathrm{F}_{3,11}=2.645 ; p=0.002\right)$, with differences occurring between natural wetlands and rice crops $(p<0.001)$. However, composition was similar between different crops $\left(\mathrm{F}_{2,8}=0.661 ; p=0.834\right)$. The indicator species of natural wetlands were: Luziola peruviana (IV=0.97; $p=0.005)$, Nymphoides indica $(\mathrm{IV}=0.87 ; p=0.006)$, Ludwigia peploides $(\mathrm{IV}=0.77 ; p=0.017)$, Heteranthera reniformis (IV=0.75; $p=0.028)$, Eleocharis spp. $(\mathrm{IV}=0.72 ; p=0.024)$, Myriophyllum aquaticum (Vell.) Verdc. (IV=0.72; $p=0.041$ ), Limnobium laevigatum (Humb. \& Bonpl. ex Willd.) Heine $(\mathrm{IV}=0.67 ; p=0.022)$, Salvinia herzogii de la Sota (IV=0.67; $p=0.006)$, Utricularia gibba L. (IV=0.65; $p=0.050)$, Salvinia minima Baker (IV=0.63; $p=0.034)$, Paspalum distichum $(\mathrm{IV}=0.62 ; p=0.050)$, Scirpus submersus $(\mathrm{IV}=0.61 ; p=0.024)$ and Cyperus berroi (IV $=0.53 ; p=0.050$ ). No indicator species were observed for new and intermediate crops, and Sagittaria montevidensis was indicator of old crops (IV=0.75; $p=0.030)$.

According to the nestedness analysis, the wetland types overlapped by $43.8 \%$, and there was nestedness between the natural wetlands and the different-aged crops $(\mathrm{p}=0.001)$. Species overlap between the different crops was $34.3 \%$, and there was significant nestedness between the fields along the age gradient from new to old crops $(p=0.035)$. The significant pair-wise associations in natural wetlands (10 pair-wise species) were higher than new (0), intermediate (1) and old crops (0). In natural wetlands there were eight positive associations and two negative associations (Figure 5). In intermediate crops Polygonum punctatum Elliott was positively associated to Pontederia cordata.

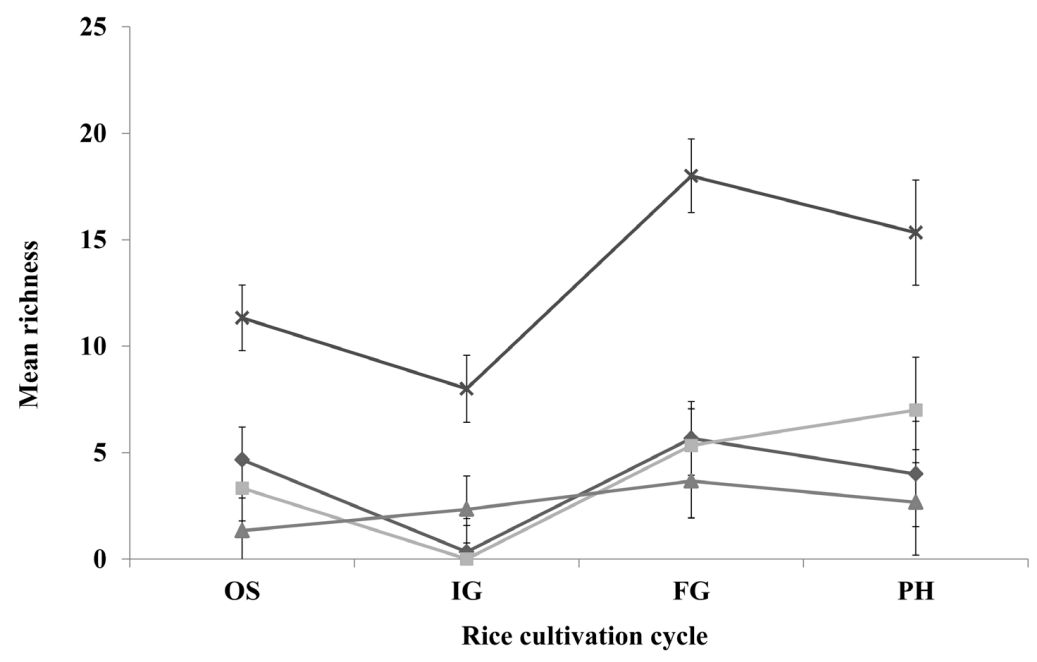

$\rightarrow$ New crops $\quad-$ Intermediate crops $\quad$-Old crops $\quad *$ Natural wetlands

Figure 2. Mean macrophyte richness $( \pm \mathrm{SE})$ of natural wetlands and crops over four phases of rice cultivation cycle in southern Brazil. The cultivation phases are: $\mathrm{OS}=$ off-season; IG = initial growth - rice emergence; FG = final growth tillering; $\mathrm{PH}=$ post-harvest. 


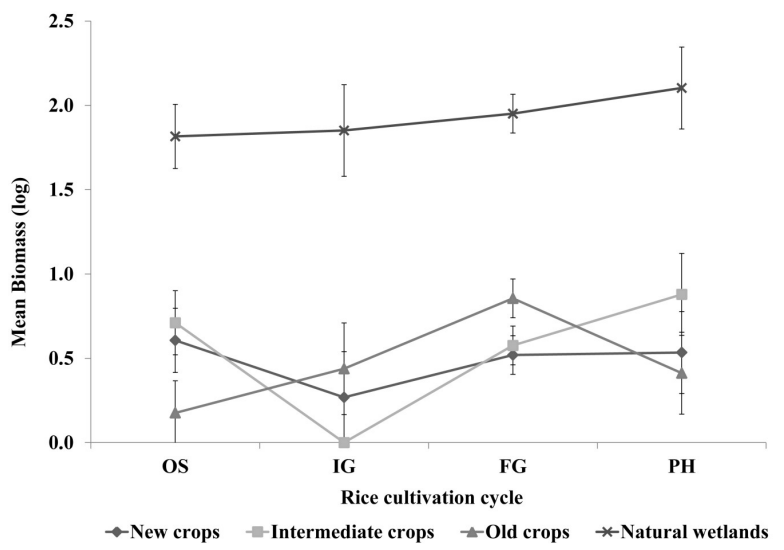

Figure 3. Mean macrophyte biomass $( \pm \mathrm{SE})$ of natural wetlands and crops over four phases of rice cultivation cycle in southern Brazil. The cultivation phases are: $\mathrm{OS}=$ off-season; $\mathrm{IG}=$ initial growth - rice emergence; FG $=$ final growth tillering; $\mathrm{PH}=$ post-harvest.

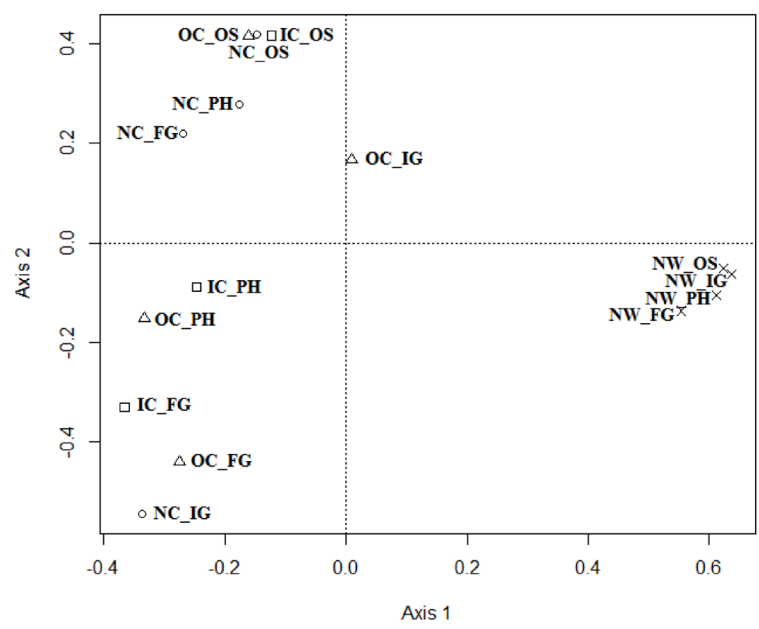

Figure 4. Ordination of natural intermittent wetlands and rice fields (new, intermediate and old crops) in the four phases of rice cultivation cycle. The first letter represents the study systems, $\mathrm{NC}=$ new crops; $\mathrm{IC}=$ intermediate crops; $\mathrm{OC}=\mathrm{old}$ crops and $\mathrm{NW}=$ natural wetlands. The following letters represents cultivation phases, $\mathrm{OS}=$ off-season; $\mathrm{IG}=$ initial growth - rice emergence; $\mathrm{FG}=$ final growth - tillering; $\mathrm{PH}=$ post-harvest.

\section{Species Co-occurrence Matrix}

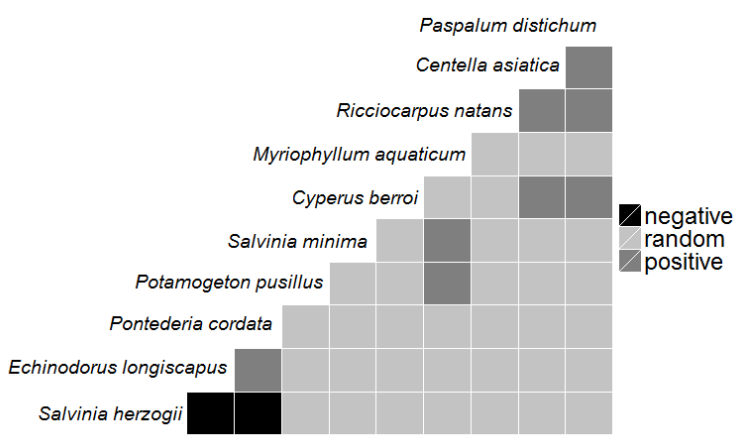

Figure 5. Positive and negative pair-wise species associations in natural wetlands. 


\section{Discussion}

Managed and artificial wetlands are important complementary habitats for freshwater biodiversity (Chester and Robson, 2013). The plant richness found in the nine different aged crops was 35 species, which is similar to that of other crops in studies developed with similar methodologies in southern Brazil (Linke et al., 2014). Nevertheless, rice field diversity was lower than that of adjacent natural wetlands (45 species) and other natural wetlands of southern Brazil (Rolon et al., 2010). Although the richness in the rice fields is lower than in natural wetlands, approximately $60 \%$ of natural wetland species were found in rice fields. This result indicates that the rice fields can contribute as complementary environments for the conservation of aquatic macrophytes.

The high richness of grasses and sedges observed in this study is similar to the pattern observed in others studies carried out in southern Brazilian rice fields and natural wetlands (Linke et al., 2014; Rolon and Maltchik, 2010; Rolon et al., 2012). However, the high contribution by hydrophytes in these rice fields differed from other studies in which emergent and amphibious species predominated (Linke et al., 2014). The greater hydrophyte dominance is not clear, however may be explained by the presence of several aquatic systems that remaining flooded over the year (rice channels, permanent wetlands and streams) near to studied rice crops and natural wetlands. Theses aquatic systems can be source of hydrophyte propagules for intermittent wetlands (natural or artificial). The macrophyte assemblage observed in the studied rice crops was predominantly perennial and native, but the most of species has low conservation value, since, the principal species found in the rice crops were plants that are often found in these ecosystems, and many are considered to be agricultural pests according to Gomes and Magalhães Junior (2004) and Lallana (2005), eg. Leersia hexandra, Eleocharis spp., Sagittaria montevidensis, Heteranthera reniformis, Ludwigia peploides and Pontederia cordata. Moreover, these species were common in the natural areas near the rice fields. The high incidence of these species in rice crops could be related to their high ecological plasticity, high dispersal ability and resistance to various environmental changes of some macrophyte species.

We expected that the predictable inundation time and depth, habitat homogenization and recurrent tillage and herbicide application would reduce plant richness and biomass according to crop age, whereas, soil contamination increases with crop age (Lepp et al., 1984), the agricultural practices used have significant implications on wildlife (McLaughlin and Mineau, 1995) and disturbance regimes drive community structure by selecting species that are able to respond to and tolerate such disturbances (Lake, 2000). However, the mean richness and biomass of aquatic plants was similar between rice fields of different ages and lower than that of natural wetlands. These results suggested that wetland conversion in rice crops impacts aquatic macrophyte diversity from the beginning of cultivation since new rice fields (up to three years) had drastically reduced aquatic plant richness and biomass. The lack of effect on the aquatic plant community in recurring cultivation could be associated with an initial selection during the first years of cultivation of species tolerant to the use of herbicides, soil management and predictable hydroperiods. Another hypothesis that could be related to high similarity in richness and biomass of crops with different ages could be the connectivity of the crops with nearby natural areas, considering that natural wetlands can serve as propagule sources for managed areas.

Macrophyte biomass did not vary throughout the rice cultivation cycle, but species richness was lower in initial growth than final growth in different aged rice crops and natural wetlands. Decreased species richness in the initial growth could be associated with the agricultural practices used in the previous period (soil preparation), which involved soil tillage, herbicide application and water management (Rolon and Maltchik, 2010). However, lower richness in the natural areas during this period is related to the natural decrease in the water level which occurs in the summer and draining to fill rice crops. Hydroperiod is one of the main drivers of aquatic macrophyte richness and composition in southern Brazil (Rolon et al., 2008).

Macrophyte composition was similar between different-aged rice crops, and there was only segregation between rice crops and natural wetlands. Furthermore, the period in which the greatest similarity occurred between different-aged rice fields was during the off-season period, which reinforces the idea that natural wetlands could function as propagule sources for rice field colonization. Besides the higher temporal beta diversity observed in rice crops indicated a lower stability these managed wetlands and it demonstrated the dependence of existence of natural wetlands in agricultural landscape. During the other cultivation periods, the rice crops do not have a clearly defined temporal pattern.

Only S. montevidensis was an indicator of rice fields, and its frequency and abundance indicated that it is characteristic of old fields. This species is commonly found in rice fields, and it may compete with rice plants for nutrients (Gomes and Magalhães Junior, 2004). On the other hand, natural wetlands had 13 indicator species, of which most were hydrophytes. Although species composition in the different-aged rice crops was not markedly different, there was nestedness in the rice fields as age increased. As the age of a rice field increases, the species that occur in a rice field are subsets of species that occur in the younger rice fields and natural wetlands. This result indicates that there is a gradual species loss as areas are cultivated more, and the species that remain are the most widely distributed (natural and managed wetlands). As expected, the non-random association in natural wetlands was higher than in rice fields. The recurrent disturbance in rice fields (agricultural practices) may reduce stability aquatic macrophyte assemblages and reduce ecological interactions. Additionally, positive associations were more common than negative ones, suggesting that facilitation 
could be more important than competition for the structure of aquatic plants assemblages.

\section{Conclusion}

Our research is the first study about the impact of cultivation repetition on aquatic macrophyte diversity. We verified that rice fields, regardless cultivation age, can act as partial substitutes for natural wetlands, but the conservation of some species still depends on the existence of natural wetlands. Species composition in rice fields is mainly constituted of widely-distributed and tolerant species. Here, we verified that macrophyte richness and biomass in rice fields was lower than natural wetlands and the species composition was different among wetland types (rice fields and natural wetlands), however our hypothesis that species richness and biomass will decrease with crop age was not confirmed. All rice crops had similar macrophyte assemblage structure (richness, biomass and species composition). However, the another hypothesis tested was confirmed, macrophyte assemblage of rice fields is a subset of natural wetlands and as, the age of a rice field increases, the species that occur in older rice field are subsets of species that occur in younger ones. This result indicated that there is a gradual species loss as areas are cultivated for different lengths of time. Only a few macrophyte species that occur in younger rice fields and natural wetlands remain in old rice fields.

\section{Acknowledgements}

This research was funded by UNISINOS (02.00.023/00-0), Conselho Nacional de Desenvolvimento Científico e Tecnológico - CNPq (473123-2010-0) and FAPERGS (PqG 02/2011). Leonardo Maltchik holds a Research Productivity Grant - CNPq (3009861/2010-6). We are thankful to all farmers that authorized the use of their rice fields for our research. Data collection complied with Brazilian laws (Sistema de Autorização e Informação em Biodiversidade - SISBIO n. 24882-2).

\section{References}

ALMEIDA-NETO, M., GUIMARÃES, P., GUIMARÃES JUNIOR, P.R., LOYOLA, R.D. and ULRICH, W., 2008. A consistent metric for nestedness analysis in ecological systems: reconciling concept and measurement. Oikos, vol. 117, no. 8, pp. 1227-1239. http:// dx.doi.org/10.1111/j.0030-1299.2008.16644.x.

BAMBARADENIYA, C.N.B. and AMERASINGHE, F.P., 2004. [viewed 24 May 2011] Biodiversity associated with the rice field agro-ecosystem in Asian countries: a brief review [online]. Colombo: International Water Management Institute. Working Paper, no. 63. Available from: http://www.iwmi.cgiar.org/Publications/ Working_Papers/working/WOR63.pdf

BAMBARADENIYA, C.N.B., EDIRISINGHE, J.P., DE SILVA, D.N., GUNATILLEKE, C.V.S., RANAWANA, K.B. and WIJEKOON, S., 2004. Biodiversity associated with an irrigated rice agroecosystem in Sri Lanka. Biodiversity and
Conservation, vol. 13, no. 9, pp. 1715-1753. http://dx.doi. org/10.1023/B:BIOC.0000029331.92656.de.

CHESTER, E.T. and ROBSON, B.J., 2013. Anthropogenic refuges for freshwater biodiversity: their ecological characteristics and management. Biological Conservation, vol. 166, pp. 64-75. http:// dx.doi.org/10.1016/j.biocon.2013.06.016.

DE CÁCERES, M., LEGENDRE, P. and MORETTI, M., 2010. Improving indicator species analysis by combining groups of sites. Oikos, vol. 119, no. 10, pp. 1674-1684. http://dx.doi. org/10.1111/j.1600-0706.2010.18334.x.

FOOD AND AGRICULTURE ORGANIZATION OF THE UNITED NATIONS - FAO, 2013 [viewed 11 September 2014]. DATABASES: FAO statistical databases [online]. Available from: http://faostat.fao.org/

GOMES, A.S., and MAGALHÃES JUNIOR, A.M., 2004. Arroz irrigado no Sul do Brasil. Brasília: Embrapa. 899 p.

GRIFFITH, D., VEECH, J. and MARSH, C., 2014 [viewed 20 September 2015]. Cooccur: probabilistic species co-occurrence analysis in $R$ [online]. Available from: https://cran.r-project.org/ web/packages/cooccur/cooccur.pdf

INTERNATIONAL BUSINESS MACHINES - IBM, 2009. IBM SPSS Modeler: software package statistical package for social sciences. Chicago: IBM.

INTERNATIONAL RESEARCH RICE INSTITUTE - IRRI [online], 2013 [viewed 11 January 2013]. Available from: http://irri.org/

LAKE, P.S., 2000. Disturbance, patchiness, and diversity in streams. Journal of the North American Benthological Society, vol. 19, no. 4, pp. 573-592. http://dx.doi.org/10.2307/1468118.

LALLANA, V.H., 2005. Lista de malezas de arroz en Entre Ríos, Argentina. Ecosistemas, vol. 14, pp. 162-167.

LAWLER, S.P., 2001. Rice fields as temporary wetlands: a review. Israel Journal of Zoology, vol. 47, no. 4, pp. 513-528. http:// dx.doi.org/10.1560/X7K3-9JG8-MH2J-XGX1.

LEPP, N.W., DICKINSON, N.M. and ORMAND, K.L., 1984. Distribution of fungicide-derived copper in soils, litter and vegetation in different aged stands of coffee (Coffea arabica L.) in Kenya. Plant and Soil, vol. 77, no. 2-3, pp. 263-270. http:// dx.doi.org/10.1007/BF02182929.

LINKE, M.G., GODOY, R.S., ROLON, A.S. and MALTCHIK, L., 2014. Can organic rice crops help conserve aquatic plants in southern Brazil wetlands? Applied Vegetation Science, vol. 17, no. 2, pp. 346-355. http://dx.doi.org/10.1111/avsc. 12069.

MALTCHIK, L. and ROLON, A.S., 2004. Is Regnellidium diphyllum Lindm. an endemic species? Acta Biologica Leopoldensia, vol. 26, pp. 145-150.

MALTCHIK, L., ROLON, A.S., STENERT, C., MACHADO, I.F. and ROCHA, O., 2011. Can rice field channels contribute to biodiversity conservation in Southern Brazilian wetlands? Revista de Biología Tropical, vol. 59, no. 4, pp. 1895-1914. PMid:22208101.

MARAMBE, B., PUSHPAKUMARA, G. and SILVA, P., 2009. Biological diversity in lowland rice fields: Sri Lankan context. In: K. YASUDA and S. YAMAMOTO, eds. Biodiversity and Agroecosystem in Rice Paddy Landscape in Monsoon Asia MARCO Symposium: Challenges for Agro-Environmental Research in Monsoon Asia. Tsukuba: NIAES, pp. 1-10. 
MCLAUGHLiN, A. and MINEAU, P., 1995. The impact of agricultural practices on biodiversity. Agriculture, Ecosystems \& Environment, vol. 55, no. 3, pp. 201-212. http://dx.doi. org/10.1016/0167-8809(95)00609-V.

PIMENTEL, D., STACHOW, U., TAKACS, D.A., BRUBAKER, H.W., DUMAS, A.R., MEANEY, J.J., ONSI, D.E. and CORZILIUS, D.B., 1992. Conserving biological diversity in agricultural/forestry systems: most biological diversity exists in human-managed ecosystems. Bioscience, vol. 42, no. 5, pp. 354-362. http://dx.doi. org/10.2307/1311782.

R CORE TEAM, 2012 [viewed 20 September 2015]. $R$ : $a$ language and environment for statistical computing [online]. Viena: R Foundation for Statistical Computing. Available from: http://www.R-project.org

REID, F.A. and HEITMEYER, M.E., 1995. Waterfowl and rice in California's Central Valley. California Agriculture, vol. 49, no. 6, pp. 62-62. http://dx.doi.org/10.3733/ca.v049n06p62.

ROLON, A.S. and MALTCHIK, L., 2010. Does flooding of rice fields after cultivation contribute to wetland plant conservation in southern Brazil? Applied Vegetation Science, vol. 13, no. 1, pp. 26-35. http://dx.doi.org/10.1111/j.1654-109X.2009.01046.x.
ROLON, A.S., HOMEM, H.F. and MALTCHIK, L., 2010. Aquatic macrophytes in natural and managed wetlands of Rio Grande do Sul State, Southern Brazil. Acta Limnologica Brasiliensia, vol. 22 , no. 2, pp. 133-146. http://dx.doi.org/10.1590/S2179975X2010000200003.

ROLON, A.S., LACERDA, T., MALTCHIK, L. and GUADAGNIN, D.L., 2008. The influence of area, habitat and water chemistry on richness and composition of macrophyte assemblages in southern Brazil wetlands. Journal of Vegetation Science, vol. 19, no. 2, pp. 221-228. http://dx.doi.org/10.3170/2008-8-18359.

ROLON, A.S., ROCHA, O. and MALTCHIK, L., 2012. Do effects of landscape factors on coastal pond macrophyte communities depend on species traits? Aquatic Botany, vol. 103, pp. 115-121. http://dx.doi.org/10.1016/j.aquabot.2012.07.004.

VALLAN, D., 2002. Effects of anthropogenic environmental changes on amphibian diversity in the rain forests of eastern Madagascar. Journal of Tropical Ecology, vol. 18, no. 05, pp. 725-742. http://dx.doi.org/10.1017/S026646740200247X.

VEECH, J.A., 2013. A probabilistic model for analyzing species co-occurrence. Global Ecology and Biogeography, vol. 22, no. 2, pp. 252-260. http://dx.doi.org/10.1111/j.1466-8238.2012.00789.x. 